\title{
PERCEPTION OF FEMALE VIRGINITY IN THE MEDIEVAL WEST AND ITS CONCEPTUALISATION IN THE MEDIEVAL WELSH LAW CODES
}

Percepción de la virginidad femenina en el Occidente medieval y su conceptualización en los códigos legislativos medievales galeses

José Antonio López Sabatel

Correo electrónico: jlopezsa13@gmail.com

1. Departamento de Historia Medieval y CC y TT Historiográficas de la UNED. Grupo de Investigación «La sociedad en la corona de Castilla en la Baja Edad Media». (Madrid, España)

Recibido: 13/03/2020 Aceptado: 08/05/2020 


\section{ABSTRACT}

This article aims to shed some light on the perception of female virginity in the medieval West. A moral, social and legal insight, heir to the religious misogynist conceptualisation that would shape the actions of communities, families, and legislators in order to safeguard, at least until marriage, that precious good as a lost Edenic symbol of the creation still unspoiled by the original sin. In this way, both premarital sex and rape of virgins are punished severely and the preservation of the maidenhead of future brides is monetarily rewarded. All this responding to the interest of a patrilineal society that endowed women and their virginity with a unique and indissoluble value as an economic asset in the different strategies aimed at establishing strong marriage alliances between the different lineages. Consequently, the worth of women as a daughter and bride would always remain, to some extent, linked to the conservation of their virginity. Such a circumstance seems evident, under its most restrictive way, in the different rules and regulations governing marriage as well as in the varied seigneurial exactions that continued to increase the income of the lordship at the cost of restraining women's sexual freedom. As the title of this article indicates, starting from a more generalized perspective, the conceptualisation of virginity has been examined in the Welsh law and more specifically in the regulation concerning women and developed from legal entities such as amobr, cowyll, and agweddi.

Keywords: Virginity; Women; Middle Ages; Marriage; Lawcodes.

\section{RESUMEN}

Este artículo pretende arrojar alguna luz sobre la percepción que se tenía de la virginidad femenina en el Occidente medieval. Una visión moral, social y legal, heredera de la conceptualización religiosa y misógina que condicionaría la actuación de las comunidades medievales, las familias y los legisladores en aras de salvaguardar, al menos hasta el matrimonio este preciado bien, como un símbolo edénico perdido de la creación aún no mancillada por el pecado original. De este modo, se castiga de manera severa tanto el sexo premarital como la violación de vírgenes y se premia monetariamente la preservación de la virginidad de las futuras novias. Todo ello respondiendo al interés de una sociedad patrilineal que dotaba a la mujer y su virginidad de un valor único e indisoluble como activo económico en las diferentes estrategias encaminadas a establecer férreas alianzas matrimoniales entre los diferentes linajes. En consecuencia, la estimación de la mujer como hija y novia siempre quedaría, en cierta medida, ligada a la conservación de su virginidad. Circunstancia esta que queda de manifiesto, bajo su forma más restrictiva, en las diferentes normas reguladoras del matrimonio, así como en las diversas exacciones de corte jurisdiccional que no dejan de incrementar el patrimonio del señorío a costa de restringir la libertad sexual de la mujer. Como el título de este artículo indica, partiendo de una perspectiva más generalizada de la virginidad se ha procedido a examinar su conceptualización en la ley galesa y más específicamente en aquella normativa concerniente a las mujeres y desarrollada a partir de figuras jurídicas tales como el amobr, cowyll, y agweddi.

Palabras clave: virginidad; mujeres; Edad Media; matrimonio; código legislativo. 


\section{INTRODUCTION}

As it will be demonstrated in this essay, virginity occupies a prominent place both in religious and moral teachings and in the most representative social and legal norms of the Medieval West. It is necessary to highlight the importance that the Church attached to virginity, celibacy, and sexual restraint, for everything that was related to the desire and pleasure of the body was considered sinful. Virginity was almost a sine qua non requirement for feminine sanctity (Cartwright, 2008). At least since the De bono conjugaly was written by Saint Augustine in the fifth century, the doctrine's stance has been firm: the sexual act is only lawful with the pursuit of procreation. Outside of marriage, outside this last purpose, there is nothing more than adultery and lust (Fossier, 1996).

In addition to this current of thought, or perhaps because of it, an anthropological tendency oriented towards objectifying women was developed. For instance, at the end of the twelfth century, the abbot of the Cistercian monastery of Perseigne described the figure of the woman in terms of feudal land tenure: God owns her body and her soul, but through the law of marriage He yields her body to the husband for use and enjoyment in usufruct (Duby, 1988, pp. 37-38). Thus, it is not surprising that women were in some cases identified as property and, consequently, their integral and intact conservation was considered a point of honour.

This is because, since the Early Middle Ages, a clear relationship had been established between land, fief, and honour (Hollyman, 1957, pp. 33-41). Additionally, vassalage ties-bonds that can be traced back to the prefeudal era and by which the subordinate formed an absolute fidelity to his lord-were developed over these ownerships (Magnou-Nortier, 1968, pp. 457-459). In this way, and given the image of women as a material good, it is no wonder that, just as a piece of land was only accepted in its entirety, women were also required to remain virginal for the wedding bed. It is also unsurprising that adultery and rape were considered crimes against honour-while one threatens the fidelity that the underling (the wife) must keep for his lord (the husband), the other violates the very integrity of the property (the woman) that the husband (the 
feoffee) pledged to protect. ${ }^{1}$ Furthermore, the essential role that women played in the game of marriage alliances, not as individuals with their own will but as valuable exchange assets, ${ }^{2}$ should not be forgotten, especially considering that love cannot exist in a marriage where one cannot love what belongs to him by right (Flori, 2001, p. 242).

\section{METHODOLOGY AND LEGAL CONTEXT}

Any approach to the elaboration of a history of women in general and their virginity in particular is limited by the idiosyncrasy of medieval sources. It is well-known that for the Christian West, sources have two characteristics that hinder the research of medieval women: first, their androcentric nature, since they were produced by men and directed to men, and, second, the irregularity concerning the quantity and quality of information on the female gender. In fact, the silence that the texts keep to the feminine for most of the Middle Ages is notorious and it is not easy to find statements coming from the hand or the mouth of women themselves. A darkness that partly seems to be lifted in the last centuries of the Middle Ages (Pallares, 2003, p. 11). As this study is limited to a previous chronology, the sources used are not unrelated to the specific aforementioned features. In this way, the following work is based on the analysis and compilation of data originating in texts from Church doctors and other leading figures of the ecclesiastical thought, literary testimonies, seigneurial requirements as well as canonical and secular laws. In short, a collection of written sources that were considered for their accessibility and suitability as the most explicit references when it comes to obtaining information about the perception of virginity in medieval times. All of these primary sources have been mostly collected and published by different authors in later studies and supported by a selective bibliography.

Among these last sources, it is worth highlighting the Welsh law codes that offer a legal context for the last part of this article. The Welsh medieval legal body remained in force in the wake of the Edwardian conquest of 1282 and was not replaced by English

\footnotetext{
${ }^{1}$ We are facing two sexual crimes, adultery and rape, so hideous that in parts of Castile were paid with death instead of with any type of monetary compensation (Sánchez Albornoz, 1956, pp. 619-622). For a greater understanding of the sexual objectification of women in medieval Castilian literature, see Cabanes Jiménez, 2005, pp. 1-10.

The image of women as an object is evident in the semantic evolution from the Latin verb rapere "to seize something” or “to abduct someone” into modern English “to rape” (Dunn, 2013, p. 2).

${ }^{2}$ To have a more complete view of this subject in medieval England, see McCarthy, 2004, pp. 78-91.
} 
law until one year after the Act of Union in 1536. Knowledge of this native legal system comes from the compilation in lawbooks of a series of manuscripts that can be classified into one of the following groups: Book of Iorwerth, Book of Blegywryd and Book of Cyfnerth. These three texts constitute the essential part of the Welsh law or Cyfraith Hywel (Law of Howel) that receives its name after Howel Dda a Welsh king considered most likely responsible for the consolidation of the Welsh law around the middle of the tenth century. However, it must be pointed out that these lawbooks are from a much later time but not earlier than the reign of Llewelyn the Great (Jenkins, 1981, p. 324). These temporal differences express the true legal essence of these compilations. Texts that in no way remained static but were continually reviewed and updated by jurists. So, three possible outcomes must be assumed: that certain regulations produced in the thirteenthfourteenth centuries were recent innovations that had not existed before, that those norms which endured from earlier times did so anachronistically as a reminiscence of the past but deprived of real enforcement, and, eventually, that some traditional provisions continued to be living law (Encyclopædia Britannica, 2019).

Undoubtedly, the most interesting information that could be extracted from the different law codes concerning virginity and its perception in Welsh society was that of the chapters devoted to the laws of women. Such laws have their own sections in these legal books and are collected and commented in the work The Welsh Law of Women edited by Dafyyd Jenkins and Morfydd E. Owen in 1980.

\section{VIRGINITY, THE CHURCH, AND MISOGYNY}

In order to think about perceptions is necessary to reflect upon mentalities, and to do this, as far as the Middle Ages is concerned, it is essential to address the Church's influence throughout the history of Western Christianity. This influence was present in all areas of everyday life: the lives of men and women of all kinds and social statuses were imbued with religious meaning (Fossier, 1984, p. 733). Europe, therefore, was shaped into a "people of believers" who shared a conception of the world whereby the material and natural was despised for the benefit of the strictly spiritual and moral (Bloch, 2002, p. 105).

This dual understanding of creation was one of the first ways of responding to the metaphysical problem of the existence of evil. Hence, the work of God is divided, where 
the creation of the material world (necessarily bad, as evil is everywhere) is opposed to that of the spiritual world, the work of the good Lord (Bonnassie, 1999, p. 77). After all, following its creation, the earthly world lost its initial Edenic innocence and evil gained power, threatening humanity with innumerable traps. Behind everything that makes the world beautiful and pleasant, including the manifestations of culture, lurk sin and the corresponding eternal damnation. The perfume of flowers, a melodious voice in the church choir, the beautiful image of a saint, and even the splendour of the house of God can lead men to perdition, his senses perverted by original $\sin ^{3}$

This dualistic vision that relates matter to evil and spirit to goodness extends to the interpretation of the individual. The body is defined as a prison of the soul, but at the same time, is tied to the original sin that Christianity describes as a sexual subject. Thus, sin is identified with the body (especially that of the woman), which is regarded as the chosen place of the devil, who is comfortable with the moral fragility of Eve's descendants. This explains that the Church gave prominence to the path of spiritual perfection through the persecution of the flesh and the sinful desires that emanate from it (Le Goff, 1999b, p. 41).

For this reason, it is not surprising that since the first centuries of Christianity, divine motherhood and perpetual virginity have been upstanding ideals bound together in the figure of Mary, making the mother of Christ a virtuous paradigm and example for all women (Salvador González, 2013, p. 14). Consequently, chastity, harassment, rejection of the sexual act, and, finally, martyrdom would all be common elements in the hagiographies of virgin martyrs since the first centuries of Christianity (Winstead, 1997, pp. 6-7). However, there is also a chance for repentance and conversion that leads from a libidinous and dissolute life to a pure, virginal asceticism, as demonstrated in the religious experiences of Pelagia and Thais (Cuadrada, 2017, pp. 22-23).

This ideology of sexual containment goes back to the doctrinal precepts of the fathers of the Latin Church. Among them, it is worth mentioning the predicaments of Saint Jerome, Gregory the Great, and Saint Augustine. According to the first, Adam and Eve remained virgins in paradise, with their bodies joining only after the downfall. All nuptials are therefore cursed. Nothing justifies marriage unless it serves to repopulate heaven by engendering virgins. Moreover, the husband (necessarily a fornicator) becomes an

3 For a more comprehensive and documented view of “medieval puritanism”, see Coulton, 1923, pp. 300 and ff. and pp. 527 and ff. 
adulterer if he happens to love his wife with a certain passion, thus making a prostitute of her. In Adversus Jovinianum, Jerome discusses all possible diatribes against women and marriage in defence of pure virginity. ${ }^{4}$

For Saint Gregory, human society is divided into two: an elite that is capable of resisting the temptations of the flesh and those men and women who have not rejected marriage. The latter are inferior because marriage is tainted by pleasure. Since Adam's sin, there is no longer copulation without pleasure because the spirit of man has lost dominion over the body. Since then, the primitive law of marriage has been transgressed (Gregorio Magno, 2009, pp. 154-164).

Saint Augustine also places those who overcome the temptations of the flesh in a prominent position, and when he meditates on the Genesis, he recognizes in Adam the spiritual part of the human condition and in Eve the sensual one. Satan triumphed when he managed to harm the spirit by weakening it through the flesh. Almost all Augustinian thought is dominated by dualism: evil comes from the body, and therefore from the woman, an inferior and carnal being. ${ }^{5}$

These authoritative opinions that involve women in the world of sin, impurity, and lust influenced the perception of them throughout the Middle Ages. ${ }^{6}$ For the medieval Church, women continued to be a wicked instrument of the devil, who, by using the lowest temptations of the flesh, have no purpose other than to separate man from God. This explains the risk that Saint Bernard perceives for the immortal soul of the married man, as "living with a woman without danger is more difficult than resuscitating a dead man” (Mâle, 2010, p. 373). ${ }^{7}$

Philosophy and religion strengthened ties in the thirteenth century, when Saint Thomas Aquinas reinterpreted the theories of Aristotle to justify the inferiority of women with respect to men and her submission to him (Rucquoi, 1985, pp. 6-7). Even for the Castilian monarchy of that time, women were more inclined than men toward vices of a

\footnotetext{
${ }^{4}$ For more information about St. Jerome’s opinions about women, virginity and marriage, see Wurtele, 1983, pp. 208-236; Oppel, 1993, pp. 1-22; Hunter, 2009, pp. 207-242.

5 To delve into the considerations of St. Augustine regarding evil, women, and virginity, see Clark, 1996; Rotelle, 2005.

${ }^{6}$ An example of the continuity of the ideals of virginity and chastity in England from the Anglo-Saxon period to the Late Middle Ages can be found in Hofmann, 2007.

${ }^{7}$ Translated from the original French version by the author of this article.
} 
sexual nature, as evidenced by the treatment given to the "weaker sex" in the Cantigas of Santa María (Pérez de Tudela, 1986, p. 68).

As it is easy to foresee, the encounter of religion, philosophy, and political authority in the same line of thinking towards women would have a very unfavourable impact on the conception and treatment dispensed to them in all social aspects throughout the Middle Ages.

\section{VIRGINITY, SOCIETY, AND RULES}

The obsessive feeling that evil came from sex took root in medieval society, thanks in large part to the power of the Church, the main agent disseminating mandatory precepts through its predicaments and teachings. Furthermore, it should not be forgotten that in the Middle Ages, religion was omnipresent and worked on two different levels. On the one hand, it was a dominant ideology supported by a temporary institution with great power; on the other hand, it was a religious belief (Le Goff, 1999a, p. 16). In fact, throughout the development of medieval Christianity, propaganda and culture were confused with each other, initially for the sole purpose of educating and converting and eventually also of making the masses more receptive to the Church's messages (Duby, 1993, p. 200).

Consequently, the sphere of the profane was much smaller than it is today. The patient not only addressed the doctor, but also made offerings to the saints or pilgrimage to a sanctuary. The castle was built with its chapel, whose particular saint and relics are believed to be more effective as a defence than military installations and facilities. Technical deficiencies forced the use of religion. Where there were no tractors, one had to beg the local saint. And the same happened with the lack of rain and hydraulic works, with the terrible fires or with the plague and other diseases (Bloch, 1924, pp. 29-30 and 280; Bordenave and Vialelle, 1973, pp. 254-25).

The perceptions that the male and patrilineal society had of women did not differ greatly from those expressed by the Church. Sinfulness and embodiment were the words that best expressed the image projected onto everything feminine, and as a result, all women, irrespective of class, were considered sexually insatiable (Freedman, 1999, p. 159). This is one of the reasons women had to marry in adolescence (i.e., in order not to be perverted while waiting for marriage). Another reason was undoubtedly to guarantee 
the continuation of the lineage by increasing the chances of a greater number of legitimate births (Klapisch-Zuber, 1999, pp. 310-311).

Thus, feminine virginity was consolidated as a conditio sine qua non to contract nuptials. Although the husband was committed to caring for his wife, there was no impediment to his having sex with other women during his bachelorhood or later in his widowhood. On the other hand, what was extolled and jealously guarded by all kinds of prohibitions in the girl-bride was virginity, and in the wife, constancy, because "if the natural debauchery of those wicked beings that are women is not monitored, they would threaten to introduce intruders born from another blood into the kinship” (Duby, 1988, p. 19). ${ }^{8}$

Therefore, there is little wonder that the memorandum drafted in 829 by the Carolingian bishops established that virginity should be preserved until the nuptials (Duby, 1999, p. 29). The Fuero of Sepúlveda, granted by Alfonso VI of León and Castile in 1076, also stipulates the obligation of women to be a virgin in order to get married (García de Cortázar, 1975, p. 434). Even beyond the Middle Ages, as late as 1587, virginity was still considered a mandatory attribute for formalizing marriage. If an Icelandic husband discovered that his wife was not a virgin, he had every right to divorce her (Arnorsdottir, 2010, p. 431). The significance of keeping virginity until the nuptials can also be deduced from the nature of the dowry in Mediterranean Europe between the fifth and eleventh centuries. During this period the dowry was the gift that the husband gave to the bride's father the morning after the wedding night in recognition of her lost virginity. With the reception of Roman law from the eleventh century onwards, the dowry became a pre-mortem inheritance that could be used to buy alliances with high-status lineages if the amount contributed was large enough (Hughes, 1978).

Given the importance attached to premarital sexual intercourse, it is not surprising that virginity tests were conducted. Although the hymen does not appear in the GrecoRoman medical literature, Christianity accepted bodily inspections for corroborating female virginity since very early times. The idea that the existence of a tissue provided the physical evidence of virginity was introduced in European medicine under the influence of Razés and Avicenna (De Koning, 1903, p. 89). The presence of the hymen

\footnotetext{
${ }^{8}$ Translated from the Spanish version by the author of this article.
} 
was an objective sign to declare marriage annulment, and virgins had to show their bodies to a group of women who would testify before the ecclesiastical court.

However, the validity of this testimony was challenged by some prominent men, such as Saint Albert the Great, who warned that there were women who used certain medications to create the false appearance of virginity before an inexperienced examiner (Stadler, 1916, p. 163). Consequently, at least in literary texts, it became necessary to go beyond conventional medical practices such as the analysis of urine and identify the virginity test as a true ordeal that the alleged virgin had to pass (Coyne Kelly, 2000, pp. 7 and 63-90). However, at this point, it should be stressed that although it is impossible to quantify the number of premarital pregnancies in medieval England, these would have been uncommon as evidenced in sixteenth-century studies that place these cases within a range of between thirteen and twenty-six per cent of all marriages (Hanawalt, 1986, p. 196).

Premarital virginity and marital fidelity were also a concern of the seigneurial system. Thus, in parts of England, the lord of the manor had the right to levy a fine upon an unchaste bondwoman if it was discovered that she had become pregnant while unmarried (leyrwite). ${ }^{9}$ In Catalonia, however, female adultery was penalized through the "evil custom” of cogucia (Cuadrada, 1988, p. 633). But what perhaps best identifies the lordship with virginity is the ius primae noctis, or the right of the lord to deflower his vassal's wife on the first wedding night. Although there is no record of this practice in the written law (Bullough, 1991, p. 166), its existence can be deduced through indirect references found both in Alfonso X of Castile's Fuero Real from 1255 and the Sentencia Arbitral de Guadalupe granted by Fernando II of Aragon in 1486 (Barros, 1993, p. 5).

However, it seems that virginity did not arouse particular interest in English common law, except in some cases of "its forceful theft” (Evans, Salih and Bernau, 2003, p. 82). The penalties for raping virgins, at least in the thirteenth century, were always more severe than those for the same crime committed against married women, widows, nuns, midwives, concubines, and prostitutes, with the convicted rapist facing the loss of his eyes and testicles (Phillips, 200, p. 132). This was because, in the mentality of the time, a young woman became socially and economically worthless once her virginity was lost. The value of a woman was in her virginity, and its loss meant the deprivation of a

\footnotetext{
${ }^{9}$ To learn more about this seigneurial burden, see Jones, 1992; Bennett, 2003.
} 
monetary asset that her father would have received from her marriage (Wallace, 2015, p. $62)$.

\section{VIRGINITY AND THE WELSH LAW CODES}

Initially, in medieval Wales, the importance placed on virginity did not differ too much from that of the rest of Western Europe. Virginity was considered a great asset in the marriage market, and its early loss represented an enormous impairment or even irreversible damage. This explains why the most respectable form of marriage always involved a longed-for virgin offered by her kin to the prospective husband (Cartwright, 2003, p. 56). ${ }^{10}$ Accordingly, one of the family's most imperative duties was to save and preserve the virginity of the future bride, which was required, as it happened in mainland Europe, for formalizing the marriage when the girl had just reached puberty.

Thus, a woman was considered marriageable between the ages of twelve and fourteen. Until then, it was a matter of honour for her kindred to safeguard her virginity from abduction and rape, as they would be demanded to vouch for her unblemished body and, according to the Colan text, also to give a surety to the spouse (Owen, 1980, p. 48). Whether or not a bride given in marriage happened to be a virgin (twyllforwyn), the husband had the right to divest himself of her, in which case she would not get anything from him (Jenkins and Owen, 1980, p.167). However, if the husband discovered that the woman was corrupted, but still spent the entire wedding night with her, the next morning, she would be able to keep all her entitlements as a legitimate wife. On the other hand, if the maidenhead of the bride was not entirely clear because she was in the late stages of her physical development, ${ }^{11}$ she would have the right to be vindicated by the oath of seven people from her kin (Jenkins, 1999, p. 49). If this did not happen, then the "false virgin" received a one-year steer with a greased tail instead of being given the fair share of marriage wealth, or agweddi, associated with a legitimate separation within the first seven years. In the unlikely event that the girl managed to successfully grab the slippery tail, she would be allowed to keep the animal; if not, she got nothing (McAll, 1980, p. 9).

\footnotetext{
${ }^{10}$ A less respectable way for a virgin to get married was through abduction although her kindred maintained the right to compel her to return (Walters, 1980, p. 117).

${ }^{11}$ For instance, any sign of childbearing, menstruation, grown breasts and pubic hair.
} 
Similar to what was occurring in the rest of Europe before the eleventh century through the payment of the dowry, in medieval Wales the virginity of the bride was also rewarded. However, unlike the dowry, this amount was not given by the husband to his father-in-law, but it would remain as part of his wife's personal assets (Williams, 2012, p. 43). Here, two terms appear that need to be addressed: agweddi and cowyll. The former refers to the share of the common marital property which the woman was entitled to upon a legitimate separation from her husband; the latter corresponds to the gift that the husband gave to the virgin bride the morning after the consummation of the marriage (Jenkins and Owen, 1980, pp. 187-188 and 196).

As was the case in neighbouring England, premarital sex was of interest to the seigneurial system. While in England this burden was known as Leyrwite, in Wales it was called amobr. This was an exaction payable to the lord of the place for the loss of virginity (Cartwright, 1997, p. 36). Originally, it was paid only once, as a sign of gratitude for the protection the king granted to virgin females. However, if a virginal woman was raped and did not know her aggressor, she would be exempt from paying the amobr because the king did not fulfil his duty to protect her (Patterson, 1988, p. 38). After the conquest, the English imported the Leyrwite to Wales, merging it with the amobr, adopting its name, and thus, assigning it the meaning of a fine for fornication, as in England.

On the other hand, the English influence did not bring the Leyrwite to either Ireland or Scotland, where there was no native seigneurial burden similar to any type of fine for out-of-wedlock sexual intercourse (Bennet, 2003, pp. 140-141). The success of the amobr in the thirteenth century was considerable, as it guaranteed a large source of income to the lords, especially to those who owned land in the March of Wales. In this way, the Marcher lords levied a fixed sum upon both free and unfree women (10s. or 20s. in the first case, half that amount in the second). What began as a Welsh inheritance designed to protect the virginity of women would, over time, become a simple pretext for increasing the lords' revenue by fining women every single time they were caught in illicit sexual acts until a formal declaration of prostitution was eventually issued (Davies, 2005, p. 137).

The Welsh legal system persecuted, from its early days, all crimes against property. Very soon, a correlation was established between violence and theft by imposing a maximum financial penalty of a dirwy of twelve-kine for these cases, among which, subject to the same fine, the crime of rape was subsequently introduced (Jones Pierce, 
1972, p. 305). As it happened in mainland Europe, the forceful theft of virginity was regarded as the worst violation a girl could suffer. Of the three main groups or redactions that form the Welsh medieval legal system known as Cyfraith Hywel, namely, Cyfnerth, Blegywryd, and Iorwerth, without a doubt the latter is the one that sheds most light on the legal procedures regarding the rape of a virgin woman. ${ }^{12}$

Whereas the fee of a twelve-kine dirwy was established as a punishment for common violation, ${ }^{13}$ the offence of taking virginity by force was considered serious enough to increase the number of fines by five. ${ }^{14}$ Three of them were related to the usual payments that involved the marriage of a virgin bride: amobr, cowyll, and agweddi, perhaps to compensate all parties (the victim and the lord) for future losses owing to the impossibility of celebrating the most traditional and respectable of Welsh weddings, or uniad o rodd cenedl. The fourth fine, called sarhaed, was paid to the girl in acknowledgement of the dishonour and insult attached to the crime. The last one was the diweirdeb, or the chastity fine-as the name implies, it was paid to compensate for the violation of the victim's free state, even if the physical condition of her virginity was completely irretrievable (Owen, 1980, p. 49). While the Iorwerth text says nothing about the defendant's refusal or inability to pay the fines, Llyfr Cyfnerth imposes testicular castration as a penalty, a punishment by which can be deduced an influence of English rape laws (Eska, 2013, pp. 151-152).

\section{CONCLUSIONS}

In Christian Europe, the Middle Ages is the time when feudalism developed, a system by which the relations of power and servitude between the lords and their vassals are shaped. The Christian doctrines that flooded all areas of life at that time were also present in these relations. The Church imposed a theocentric vision of the world, which leads to total control of everyday life. Sexuality in the Middle Ages was seen as something sinful, reprehensible and dangerous, but also as the most dreamed, meditated and secretly desired

\footnotetext{
${ }^{12}$ While the Iorweth manuscripts are the oldest as they are probably compiled in the first half of the thirteenth century, it is also true that they represent a more developed version of the laws (Roberts, 2011, p. 2)

13 Payable to the king.

${ }^{14}$ However, it should not be forgotten that in the event that a woman claimed she was still a virgin at the time of the rape, the accused had the right to subject her to a virginity test. (Jenkins and Owen, 1980, p. 177).
} 
of all things. The Church imposed the idea on medieval society that sex is only possible within marriage and must have an exclusively reproductive purpose. Medieval thinking was influenced by the Church, and, therefore, virginity became the ideal state for returning to the prelapsarian situation - that is, before the original sin. If the laws and social norms throughout the Medieval West agreed on anything, it was the importance given to female virginity before marriage, so much so that virginity was rewarded (cowyll, dowry before the eleventh century). Meanwhile, premarital and out-of-wedlock sexual intercourse were subject to seigneurial exactions (leyrwite, bedemund, cogucia), thus increasing the lord's revenue.

Virginity was not only an economic asset for the lord but also for the virgin girl's kindred due, in large part, to the key role played by women on the great chessboard of marriage alliances. A bride's anticipated loss of virginity meant not only a severe financial setback but also a serious family dishonour, which certainly explains the harshness of the penalties for raping a virgin. Failing to keep this physical and moral condition meant that a woman had to contribute much more money to the marriage to compensate the husband for denying his right to deflower her.

The existence of a previous man, of an initiator who was not the husband, meant that the woman did not belong to the group of "good" women, befalling on her the suspicion of being prone to adultery. The remote possibility that the prospective wife was a potential adulteress was something that men preferred not to be exposed, given the risk that his manhood and value before society could be called into question. In this way, it is not surprising that in Wales, a false virgin given in marriage lost all her rights to enjoy the common marital property and to receive the corresponding morning gift, as well as being provided with only one chance to keep a one-year steer, as long as she went successfully through a ritual whose purpose was to subject her to public scorn and derision. 


\section{REFERENCES}

ArnorsdotTIR, Agnes Siggerour. Property and Virginity: The Christianization of Marriage in Medieval Iceland 1200-1600. Aarhus: Aarhus University Press, 2010.

Barros Guimerans, Carlos. Rito y Violación: Derecho de Pernada en la Baja Edad Media. In: Historia social. 1993, vol. 16, pp. 3-18.

BenNETT, Judith M. Writing Fornication: Medieval Leyrwite and its Historians. In: Transactions of the Royal Historical Society. 2003, vol. 13, pp. 131-162.

Bloch, Marc. Les Rois Thaumaturges, Étude sur le Caractère Surnaturel Attribué la Puissance Royale, Particulièrement en France et en Angleterre. Strasbourg: Publications de la Faculté des lettres de l’Université de Strasbourg, 1924.

BLOCH, Marc. La Sociedad Feudal. Madrid: Akal, 2002.

Bonnassie, Pierre. Vocabulario Básico de la Historia Medieval. Barcelona: Crítica, 1999.

Bordenave, Jean; Vialelle, Michel. La Mentalité Religieuse des Paysans de l'Albigeois Médiéval. Toulouse: Privat, 1973.

Bullough, Vern L. Ius Primae Noctis or Droit du Seigneur. In: The Journal of Sex Research. 1991, vol. 28, núm. 1, pp. 163-166.

Cabanes Jiménez, Pilar. El Deseo Femenino a la Luz de Algunas Composiciones Literarias Medievales. In: Lemir: Revista de Literatura Española Medieval y del Renacimiento. 2005, vol. 9, pp. 1-10.

CARTWRIGHT, Jane. The Desire to Corrupt: Convent and Community in Medieval Wales. In: Watt, Diane (ed.). Medieval Women In Their Communities. Toronto: University of Toronto Press, 1997, pp. 20-48.

CARTWRIGHT, Jane. Virginity and Chastity Tests in Medieval Welsh Prose. In: Evans, Ruth; Salih, Sarah; Bernau, Anke (eds.). Medieval Virginities. Toronto: University of Toronto Press, 2003.

CARTWRight, Jane. Feminine Sanctity and Spirituality in Medieval Wales. Cardiff: University of Wales Press, 2008.

Clark, Elizabeth A. (ed.). St. Augustine on Marriage and Sexuality. Washington, D.C.: The Catholic University of America Press, 1996.

Coulton, George Gordon. Five Centuries of Religion (vol. 1). Cambridge: Cambridge University Press, 1923.

Coyne Kelly, Kathleen. Performing Virginity and Testing Chastity in the Middle Ages. London: Routledge, 2000.

CuAdradA, Coral. El Maresme Medieval: Hàbitat, Economia i Societat, Segles X-XIV. Mataró: Rafael Dalmau, 1988.

CuADRADA, Coral. La Lujuria y los Secretos de las Mujeres en la Edad Media. In: Temas de mujeres. 2017, pp. 19-40.

DAVIES, Robert Rees. Lordship and Society in the March of Wales 1282-1400. Oxford: Oxford University Press, 2005.

De Koning, Pieter. Trois Traites d'Anatomie Arabes par Muhammad Ibn Zakariyya AlRazi, 'Ali Ibn Al-'Abbas, et 'Ali Ibn Sina; Text Inedit de Deux Traites. Leiden: Brill, 1903.

DuBY, Georges. El amor en la Edad Media y otros ensayos. Madrid: Alianza Editorial, 1988.

DuBY, Georges. Hombres y Estructuras de la Edad Media. Madrid: Siglo XXI, 1993.

DuBY, Georges. El Caballero, la Mujer y el Cura. Madrid: Taurus, 1999. 
DunN, Caroline. Stolen Women in Medieval England: Rape, Abduction, and Adultery, 1100-1500. Cambridge: Cambridge University Press, 2013.

ENCYCLOP ÆDiA BRitANNICA. Welsh law. 2019. [Access Date: April 16, 2020]. Available on: https://www.britannica.com/topic/Welsh-law

ESKA, Charlene M. Imbrued in their Owne Bloud: Castration in Early Welsh and Irish Sources. In: Tracy, Larissa (ed.). Castration and Culture in the Middle Ages. Cambridge: D.S. Brewer, 2013.

Evans, Ruth; SALIH, Sarah; BERnAU, Anke. Medieval Virginities. Toronto: University of Toronto Press, 2003.

FLORI, Jean. Caballeros y Caballería en la Edad Media. Barcelona: Paidós, 2001.

FossIER, Robert. La Infancia de Europa. Siglos X-XII. Aspectos Económicos y Sociales. 2/ Estructuras y Problemas. Barcelona: Editorial Labor, 1984.

Fossier, Robert. La Sociedad Medieval. Barcelona: Crítica, 1996.

FreEdMan, Paul. Images of the Medieval Peasant. Stanford: Stanford University Press, 1999.

GARCía DE CoRTÁzAr, José Ángel. Nueva Historia de España en sus Textos. Edad Media. Santiago de Compostela: Pico Sacro, 1975.

Gregorio Magno. Regla Pastoral. tr. sp. Paulino Gallardo. Madrid: Biblioteca de Autores Cristianos, 2009.

Hanawalt, Barbara A. The Ties That Bound. Peasant Families in Medieval England. Oxford: Oxford University Press, 1986.

Hofmann, Melissa A. Virginity and Chastity for Women in Late Antiquity, Anglo-Saxon England, and Late Medieval England: On the Continuity of Ideas. In: TCNJ Journal of Student Scholarship. 2007, vol. 8, pp. 1-10.

Hollyman, Kenneth James. Le Développement du Vocabulaire Féodal en France Pendant le Haut Moyen Âge. Étude Sémantique. Paris: Minard, 1957.

Hughes, Diane Owen. From Brideprice to Dowry in Mediterranean Europe. In: Journal of Family History. 1978, vol. 3, pp. 262-296.

Hunter, David G. Marriage, Celibacy, and Heresy in Ancient Christianity: The Jovinianist Controversy. Oxford: Oxford University Press, 2009.

Jenkins, Dafydd. The Medieval Welsh Idea of Law. In: Tijdschrift voor Rechtsgeschiedenis. 1981, vol. 49, pp. 323-348.

Jenkins, Dafydd. The Laws of Women. In: Jenkins, Dafydd (ed.). Hywel Dda. The Law: Law Texts of Medieval Wales. Llandysul: Gomer Press, 1999, pp. 45-61.

JenKIns, Dafydd; OwEn, Morfydd (eds.). The Welsh Law of Women. Cardiff: University of Wales Press, 1980.

JonEs, Evan David. The Medieval Leyrwite: A Historical Note on Female Fornication. In: The English Historical Review. 1992, vol. 425, pp. 945-953.

Jones PierCE, Thomas. Medieval Welsh Society. Selected Essays. Cardiff: University of Wales Press, 1972.

KLAPISCH-ZuBER, Christine. La Mujer y la Familia. In: Le Goff, Jacques (ed.). El Hombre Medieval. Madrid: Alianza Editorial, 1999, pp. 295-322.

LE Goff, Jacques. La Civilización del Occidente Medieval. Barcelona: Paidós, 1999a.

Le Goff, Jacques. Lo Maravilloso y lo Cotidiano en el Occidente Medieval. Madrid: Altaya, 1999b.

Magnou-NorTier, Elisabeth. Fidélité et Féodalité Méridionales d'Après les Serments de Fidélité (Xe - Début XIIe Siècle). In: Annales du Midi: revue de la France méridionale. 1968, vol. 89, pp. 457-484.

MÂLE, Emile. L'Art Religieux du XII Siècle en France (A New Release of the Original 1922 Edition). Paris: Kessinger Pub Co, 2010. 
McAlL, Christopher. The Normal Paradigms of a Woman's Life in the Irish and Welsh Texts. In: Jenkins, Dafydd; Owen, Morfydd E. (eds.). The Welsh Law of Women Cardiff: University of Wales Press, 1980, pp. 7-22.

MCCARThY, Conor. Marriage in Medieval England: Law, Literature, and Practice. Rochester, NY: The Boydell Press, 2004.

OPPEL, John. Saint Jerome and the History of Sex. In: Viator. 1993, vol. 24, pp. 1-22.

Owen, Morfydd E. Shame and Reparation: Women's Place in the Kin. In: Jenkins, Dafydd; Owen, Morfydd E. (eds.). The Welsh Law of Women. Cardiff: University of Wales Press, 1980, pp. 40-68.

Pallares Méndez, María del Carmen. A Vida das Mulleres na Galicia Medieval (11001500). Santiago de Compostela: Universidade de Santiago de Compostela, 2003.

PAtTerson, Nery. Woman as Vassal: Gender Symmetry in Medieval Wales. In: Proceedings of the Harvard Celtic Colloquium. 1988, vol. 8, pp. 31-45.

PÉREZ DE Tudela Y Velasco, María Isabel. El Tratamiento de la Mujer en las Cantigas de Santa María. In: La Condición de la Mujer en la Edad Media: Actas del Coloquio Celebrado en la Casa de Velázquez, del 5 al 7 de noviembre de 1984. Madrid: Universidad Complutense de Madrid, 1986, pp. 51-74.

PHILLIPS, Kim Marie. Written on the Body: Reading Rape from the Twelfth to Fifteenth Centuries. In: Menuge, Noël James (ed.). Medieval Women and The Law. Woodbridge: The Boydell Press, 2000, pp. 125-144.

RoBerts, Sara Elin. Llawysgrif Pomffred. An Edition and study of Peniarth MS 259B. Leiden: Brill, 2011.

Rotelle, John E. (ed.). Saint Augustine. Marriage and Virginity (Works of Saint Augustine: A Translation for the 21st Century). New York: New City Press, 2005.

RuCQuOI, Adeline. La Mujer Medieval. Madrid: Cuadernos de Historia 16 (núm. 262), 1985.

SAlvador GonzÁlez, José María. Benedicta in Mulieribus: La Virgen María como Paradigma de la Mujer en la Tradición Patrística y su Posible Reflejo en la Pintura Gótica Española. In: Mirabilia: Revista Electrónica de Historia Antigua e Medieval. 2013, vol. 17, pp. 11-51.

SÁNCHEZ AlboRnOZ, Claudio. España, un Enigma Histórico. Buenos Aires: Sudamericana, 1956.

StadleR, Hermann (ed.). Albertus Magnus. De Animalibus. Münster: Aschendorff, 1916.

WALlaCE, Ashley Nicole. Jeopardized Virginity an Analysis of Rape and Spiritual Virginity in Medieval Europe. [Unpublished MA thesis]. Tallahassee: Florida State University, 2015.

WALTERS, Dafydd B. The European Legal Context of the Welsh Law of Matrimonial Property. In: Jenkins, Dafydd; Owen, Morfydd E. (eds.). The Welsh Law of Women. Cardiff: University of Wales Press, 1980, pp. 115-131.

Williams, Patricia (ed.). Historical Texts from Medieval Wales. London: The Modern Humanities Research Association, 2012.

WinsteAD, Karen A. Virgin Martyrs: Legends of Sainthood in Late Medieval England. Ithaca, N.Y.: Cornell University Press, 1997.

Wurtele, Douglas. The Predicament of Chaucer's Wife of Bath: St. Jerome on Virginity. In: Florilegium. 1983, vol. 5, pp. 208-236. 